\title{
Optimizing Laccase Production in Auricularia Cornea by Submerged Fermentation With Wheat Bran Extract: Applications in Decolorization of Malachite Green Dye
}

\section{Li Meng}

Shandong Agricultural University

Xiaoran Bai ( $\sim$ bxr777@126.com )

Shandong Agricultural University https://orcid.org/0000-0002-9145-7748

Qingji Wang

Shandong Agricultural University

Xiaobo Li

Shandong mushroom industrial technology innonation research institute

Shaoyan Zhang

Shandong Agricultural University

Li Wang

Shandong Agricultural University

Wei Wang

Shandong Agricultural University

Zhuang Li

Shandong Agricultural University

Original article

Keywords: Wood ear mushroom, Laccase, Decolorization, Biodegradation

Posted Date: April 29th, 2021

DOl: https://doi.org/10.21203/rs.3.rs-464777/v1

License: (c) (i) This work is licensed under a Creative Commons Attribution 4.0 International License. Read Full License 
2 Optimizing laccase production in Auricularia cornea by submerged fermentation with

3 wheat bran extract: Applications in decolorization of malachite green dye

4

$5 \quad$ Li Menga, \#, Xiao-ran Baia, \#, Qing-ji Wang ${ }^{\text {a }}$, Xiao-bo Li ${ }^{\text {b }}$, Shao-yan Zhang ${ }^{\text {a }}$, Li Wang ${ }^{\text {a }}$,

6 Wei Wang ${ }^{\mathrm{a}}$, Zhuang $\mathrm{Li}^{\mathrm{a}}$, *

$7 \quad{ }^{\text {a }}$ Shandong Provincial Key Laboratory of Agricultural Microbiology, College of Plant

8 Protection, Shandong Agricultural University, Tai'an 271018, China

9 b Shandong Mushroom Industiral Technology Innonation Research Institute, Jining, $10 \quad 272000$, China

$11 \quad$ \#The authors contributed equally to this work.

$12 \quad$ * Corresponding author: liz552@126.com 
Abstract:

Wheat bran extract may enhance laccase activity of Auricularia cornea in submerged

15 fermentation. The laccase activity of $A$. cornea was maximal $(768.78 \mathrm{U} / \mathrm{mL})$ at $26.9^{\circ} \mathrm{C}, \mathrm{pH} 5$,

16 a time point of $6 \mathrm{~d}, 22 \mathrm{~h}$, and an inducer concentration of $10 \%$. Laccase from A. cornea AC5

17 decolorized $83.27 \%$ of $75 \mathrm{mg} / \mathrm{L}$ malachite green within $12 \mathrm{~h}$. High performance liquid 18 chromatography (HPLC) analysis of the extracted metabolites suggested that the

19 decolorization occurred through biodegradation. Malachite green induced cytotoxic damage

20 including formation of a micronucleus and chromosome bridge at anaphase. Degradation

21 products of malachite green proved to be less toxic and had negligible effects on

22 chromosomal aberrations.

23 Key words:

24 Wood ear mushroom, Laccase, Decolorization, Biodegradation 


\section{Introduction}

Robust growth of the worldwide textile industry in recent years has driven a commensurate increase in the use of synthetic dyes and consequent environmental pollution due to the discharge of contaminated wastewater (Saratale et al. 2011). Triphenylmethane dyes, including malachite green, are among the most widely used group of synthetic colorants for dyeing cotton, wool, silk, nylon, etc. (Ayed et al. 2009). However, malachite green is highly toxic to mammalian cells. It promotes hepatic tumor formation in rodents and causes reproductive abnormalities in rabbits and fish (Fernandes et al. 1991; Rao 1995). Moreover, removal of dye chemicals from dye-bearing wastewater is a complex problem because of difficulty in wastewater treatment using conventional methods (Kumar et al. 2006), such as, ozonation, photooxidation, electrocoagulation, adsorption, reverse osmosis, membrane filtration, etc. (Daneshvar et al. 2007; Jain et al. 2003). Therefore, developing a new, practical method for their removal from wastewater is of utmost importance (Ayed et al. 2011).

Auricularia cornea is a type of white-rot fungus which has been intensively studied for its dye-decolorizing properties. Non-specific lignin-modifying enzymes in white-rot fungi enable them to transform a wide range of organic compounds (Wesenberg et al. 2003). There are a considerable number of recent studies on decolorization and degradation of individual synthetic dyes including triphenylmethane (Vršanská et al. 2018), azo (Tauber et al. 2005), anthraquinone (Tychanowicz et al. 2004), etc. by white-rot fungi (Asgher et al. 2006). The biodegradation ability of white-rot fungi is assumed to be associated with the production of lignolytic enzymes such as lignin peroxidase and laccase (Couto and Herrera 2006; Ghodake et al. 2008). In addition, most studies have found that fungi with the highest laccase activity, 
for instance, Trametes versicolor (Li et al. 2014), Fomes fomentarius (Neifar et al. 2011), Ganoderma sp. (Zhuo et al. 2011), Agaricus bisporus (Othman et al. 2018), Thelephora sp. (Selvam K et al. 2003), and Pleurotus sp. (Tychanowicz et al. 2004; Meng and Li 2017) can decolorize dyes the most efficiently (Erkurt et al. 2007). This suggests that laccase plays a key role in this process.

Laccase (EC 1.10.3.2, benzenediol/oxygen oxidoreductase) is a multicopper oxidase, widely distributed among plants, fungi, and bacteria (Claus 2003). When different sources of laccase catalyze the same substrate, the enzymatic characteristics are different. When the same laccase catalyzes different substrates, the enzymatic characteristics are also different. In order to better apply the use of laccase for remediation, optimization of cultivation conditions is an important strategy to maximize laccase enzyme productivity (Bhattacharya et al. 2011). Some researchers have reported increases in laccase activity following the addition of different inducers to media, such as veratryl alcohol, Tween-80, copper sulphate or 2,5-xylidine (Churapa et al. 2007; Sondhi and Saini 2019; Galhaup and Haltrich 2001). In addition, many studies have shown that the nitrogen $(\mathrm{N})$ source, as one of the important nutritional factors in fungal metabolism, can regulate the production of ligninolytic enzymes in wood-rotting basidiomycetes (Galhaup et al. 2002; Sun et al. 2004). Laccase production by Trametes modesta can be significantly influenced by wheat bran, yeast extract and incubation temperature (Nyanhongo et al. 2002). The laccase activity of Ganoderma lucidum 447 was the highest in submerged fermentation processes using wheat or soybean bran (Songulashvili et al. 2007), with evidence that enzyme activity was influenced the $\mathrm{N}$ source.

This study aims to investigate the potential of $A$. cornea for decolorizing a solution 
containing a cationic textile dye, malachite green. Correlation of laccase activity with various parameters (time, temperature, inducer concentration and $\mathrm{pH}$ ) were characterized. The cytogenotoxicity of the products formed after decolorization were studied.

\section{Materials and methods}

\section{Organisms and preparation of crude enzyme solution}

An A. cornea AC5 strain was provided by the Collection Center of Mushrooms in Jilin Agricultural University. The strain was maintained on potato dextrose agar (PDA) medium at $18^{\circ} \mathrm{C}$. Five $0.7-\mathrm{cm}$ potato dextrose agar discs of mycelia from a Petri dish were inoculated in a flask with $100 \mathrm{~mL}$ complete yeast medium (CYM) (1\% maltose, $2 \%$ glucose, $0.2 \%$ yeast extract, $0.2 \%$ tryptone, $0.05 \% \mathrm{MgSO}_{4} \cdot 7 \mathrm{H}_{2} \mathrm{O}, 0.46 \% \mathrm{KH}_{2} \mathrm{PO}_{4}$ ), followed by shaking the culture at $26^{\circ} \mathrm{C}$ and $160 \mathrm{r} / \mathrm{min}$. After seven days, the cultures were centrifuged at $6000 \mathrm{r} / \mathrm{min}$ for 10min, and the cell-free supernatant was used as a crude enzyme solution.

\section{Effects of different physicochemical parameters on laccase activity}

To obtain a representative picture of laccase activity, preliminary experiments were conducted at different temperatures $\left(22-34{ }^{\circ} \mathrm{C}\right)$ at $\mathrm{pH} 5$, at various other $\mathrm{pH}$ ranges (3-9) at $26^{\circ} \mathrm{C}$, as well as at $\mathrm{pH} 5$, at different inducer concentrations $(0-20 \%)$ at $26^{\circ} \mathrm{C}$ and $\mathrm{pH} 5$, and with different cultivation periods (1-9 d) at $26^{\circ} \mathrm{C}$ and $\mathrm{pH}$. The factors affecting the laccase production of A. cornea AC5 were screened on the basis of these preliminary experiments.

The effects of these parameters on laccase activity were examined by varying only one factor at a time, where time, temperature, inducer concentration and $\mathrm{pH}$ were considered as key variables. All of these experiments were performed under aseptic conditions under isothermal incubation at a constant agitation of $160 \mathrm{rpm}$ in a $250 \mathrm{~mL}$ Erlenmeyer flask with a $5 \%$ inducer 
concentration (except experiments measuring the effects of different inducer concentrations).

\section{Laccase activity assay}

Laccase activity was determined by monitoring the $\mathrm{A}_{420}$ change related to the rate of oxidation of $1 \mu \mathrm{mol}$ of 2,2-azino-bis-[3-ethylthiazoline-6-sulfonate] (ABTS) in $20 \mathrm{mM}$ of a sodium acetate buffer ( $\mathrm{pH} 4.5)$. Assays were performed in a $1 \mathrm{~mL}$ spectrophotometric cuvette at $30{ }^{\circ} \mathrm{C}$ with an adequately diluted culture liquid. One unit of laccase activity was defined as the amount of enzyme catalyzing the oxidation of $1 \mu \mathrm{mol}$ of ABTS per minute.

\section{Selection of significant parameters by Plackett-Burman (PB)}

A set of 27 experiments was designed using the Plackett-Burman design of Design Expert (version 8.0.6.1) software for four variables (Table 1,2) that were analyzed as possible factors affecting production. The parameters evaluated were as follows: A: time, B: temperature, $\mathrm{C}$ : inducer concentration, $\mathrm{D}: \mathrm{pH}$. Ideal concentration levels were calculated based on single factor analysis. All the trials were carried out in triplicate and the mean laccase yield was calculated.

\section{Optimization of laccase production using response surface methodology (RSM)}

Central composite design (CCD) of RSM in Design Expert (version 8.0.6.1) was employed at an $\alpha$ value of \pm 1 to further optimize the levels of significant variables (Table 1). Laccase activity was recorded as the response. Response data were analyzed by the software to generate $3 \mathrm{D}$ plots indicating the optimum conditions and interactions among these factors. A regression analysis was performed on the data obtained. A second-order polynomial equation was used to fit the data by a multiple regression procedure. A quadratic model was obtained as per the following equation: 


$$
\mathrm{Y}=\delta_{0}+\Sigma \delta_{\mathrm{i}} \mathrm{V}_{\mathrm{i}}+\Sigma \delta_{\mathrm{ii}} \mathrm{V}_{\mathrm{i} 2}+\Sigma \delta_{\mathrm{ij}} \mathrm{V}_{\mathrm{i}} \mathrm{V}_{\mathrm{j}}
$$

Where, $\mathrm{Y}$ is the predicted response [laccase activity $(\mathrm{U} / \mathrm{mL})], \delta_{0}$ is the constant term, $\delta_{\mathrm{i}}$ the linear coefficients, $\delta_{\mathrm{ii}}$ the squared coefficients and $\delta_{\mathrm{ij}}$ the interaction coefficients. The quality of fit by the polynomial model equation was expressed using the coefficient of determination, $\mathrm{R}^{2}$.

\section{Analytical methods in dye decolorization}

Dye colors were determined spectrophotometrically (Abadulla et al. 2000). Color removal was determined based on absorbance in the UV-visible spectrum using a previously described equation (Jadhav et al. 2008). The decolorization rate (\%) was calculated as $\left(A_{i}-A_{t}\right)$ $/ A_{i} \times 100$, where $A_{i}$ and $A_{t}$ are the initial and final absorbance units, respectively.

The decolorization of malachite green dye was determined by High Performance Liquid Chromatography (HPLC). Chromatographic separation of samples was performed using an Eclipse Plus $95 \AA$ C18 column $(4.5 \times 250 \mathrm{~mm}, 5 \mu \mathrm{m})$. The column temperature was maintained at $30{ }^{\circ} \mathrm{C}$. Mobile phase A was $0.125 \mathrm{~mol} / \mathrm{mL}$ ammonium acetate solution and mobile phase $\mathrm{B}$ was acetonitrile. The elution profile was set as following: $0.01 \mathrm{~min}, 80 \% \mathrm{~B} ; 20 \mathrm{~min}, 80 \% \mathrm{~B}$. The flow rate was $1.00 \mathrm{~mL} / \mathrm{min}$, the injection volume was $20 \mu \mathrm{L}$ and absorbance was measured at $614 \mathrm{~nm}$.

\section{Cytogenotoxicity test}

Allium sativum was used to study the cytotoxicity of malachite green. The meristematic cells of root tips were exposed to malachite green dye for $24 \mathrm{~h}$. These root tips were later fixed in Carnoy's Fluid for 3h. Fixation was followed with treatment with $1 \mathrm{M} \mathrm{HCl}$ at $60{ }^{\circ} \mathrm{C}$ for $8 \mathrm{~min}$, followed by a distilled water rinse. Root tips were squashed on a glass slide in 
Schiff reagent for $10 \mathrm{~min}$. The prepared slide samples were sealed with a coverslip and observed at $400 \times$ and $1000 \times$ magnification.

\section{Results}

Determination of optimum time, temperature, inducer concentration and $\mathrm{pH}$ for laccase activity

Adaptation of the fungus to a broader range in $\mathrm{pH}$ and temperature may improve its suitability for laccase production. Figure 1C shows that laccase activity was maximal (625.14 $\mathrm{U} / \mathrm{mL}$ ) at $7.5 \%$ inducer concentration. The laccase activity was $386.61 \mathrm{U} / \mathrm{mL}, 321 \mathrm{U} / \mathrm{mL}$ and $346.94 \mathrm{U} / \mathrm{mL}$ at $9 \mathrm{~d}, 26^{\circ} \mathrm{C}$ and $\mathrm{pH} 5$, respectively (Figure 1A, B, D). The laccase activity of $A$. cornea increased proportionally with culture time. However, the liquid medium became considerably more viscous by the $9^{\text {th }}$ day. Therefore, we focused on laccase activity at 3-7 d for further study.

\section{Optimization of laccase activity of $A$. cornea AC5 using CCD by RSM approach}

The experiments were conducted as per the combination listed in Table 2. Multiple regression analysis was carried out and fitted to a second degree polynomial equation, which relates dependent and independent variables, as indicated:

$$
\begin{aligned}
& \mathrm{R} 1=576.47983+33.275152779167 \mathrm{~A}+156.64087497083 \mathrm{~B}-69.960944458333 \mathrm{C}-115.6875 \\
& 0001667 \mathrm{D}+101.702166625 \mathrm{AB}-11.748708375 \mathrm{AC}+35.5289166625 \mathrm{AD}-21.723541675 \mathrm{BC}-11 \\
& 8.0526667125 \mathrm{BD}-175.587916675 \mathrm{CD}-171.30556249792 \mathrm{~A}^{2}-143.77193753542 \mathrm{~B}^{2}-16.914166 \\
& 679167 \mathrm{C}^{2}-113.57749997917 \mathrm{D}^{2}
\end{aligned}
$$

The fitness of the quadratic polynomial equation generated was statistically verified by an F-test (ANOVA). Table 3 shows the analysis of variance (ANOVA) for the generated 
model for the process, with a significance level of $p<0.05$. An $\mathrm{R}^{2}$ value of $99.93 \%$ measured for laccase production indicated a good fit for the generated model. The "Lack of Fit" $p$-value of 0.0706 (non-significant) supported this inference. The variations in responses as a function of the assessed parameters are represented in a 3D response surface plot as shown in Figure 2. A response surface contour map directly reflects the influence of various factors on the value of a specific response, so as to determine the best process parameters and their interactions. The higher the slope of the surface, the steeper the slope, indicating that a significant interaction beyond a certain degree of slope. In addition, laccase activity decreased gradually when the color of the surface changed from red to green. The center of the smallest ellipse of the contour on the surface was the highest point of the response surface, corresponding to maximal enzyme activity. The model forecasted that peak laccase production of $A$. cornea was $787.87 \mathrm{U} / \mathrm{mL}$ at $26.9^{\circ} \mathrm{C}$ and $\mathrm{pH} 5$, with an incubation time of $6 \mathrm{~d}, 22 \mathrm{~h}$, and an inducer concentration of $10 \%$. The optimal extraction conditions were verified experimentally, and the results indicated that the laccase yield was $768.78 \mathrm{U} / \mathrm{mL}$, which was consistent with the model.

\section{Decolorization of malachite green dye}

Laccase from A. cornea AC5 decolorized $83.27 \%$ of malachite green at an initial concentration of $75 \mathrm{mg} / \mathrm{L}$ within $12 \mathrm{~h}$. High performance liquid chromatography (HPLC) analysis results revealed that the peak elution time of malachite green was at $2.373 \mathrm{~min}$, the peak height was $696.445 \mathrm{mAU}$ and the peak area was $34.595 \mathrm{mAU}^{*}$ min (Figure $3 \mathrm{~A}$ ). Degraded malachite green dye was also detected by HPLC, with a peak height of 16.479 $\mathrm{mAu}$ at an elution time of $1.997 \mathrm{~min}$; the peak area was $0.653 \mathrm{mAu} *$ min (Figure $3 \mathrm{~B}$ ). HPLC 
analysis of the extracted metabolites suggested that the decolorization occurred through biodegradation.

\section{Cytogenotoxicity}

Malachite green dye is known to generate carcinogenic compounds after breakdown in some instances. Allium sativum is a well-accepted and reliable model for testing cytogenotoxic effects. As demonstrated in Figure 4, malachite green treatment was associated with an increase in chromosomal aberrations. Malachite green induced cytotoxic damage including micronucleus (Figure 4A) and chromosome bridge at anaphase (Figure 4B). The degradation products of malachite green after treatment with A. cornea AC5 were considerably less cytogenotoxic and had a negligible effect on induced chromosomal aberrations.

\section{Discussion}

In this study, we found that wheat bran extract significantly enhanced the laccase activity of A. cornea in submerged fermentation. This result was consistent with that wheat bran could improve the bacterial laccase activity (Muthukumarasamy et al. 2015). The concentration of wheat bran extract was directly correlated to the production of laccase up to a concentration of $7.5 \%$. Above this concentration, laccase production was inversely correlated to the concentration of wheat bran extract. This suggests that the presence of wheat bran extract increased the amount of $\mathrm{N}$ in the liquid media (Bagewadi et al. 2017). Above a certain point, an excess N:C ratio increases the viscosity of the fermentation broth, which is not conducive to the growth of mycelia. 
instance, triphenylmethane, anthraquinone, thiazine, azo, etc. In this study, we found that laccase from A. cornea AC5 degraded the triphenylmethane dye, malachite green. The decolorization rate of malachite green $(75 \mathrm{mg} / \mathrm{L})$ was $83.27 \%$ within $12 \mathrm{~h}$. To understand the bioremediation mechanisms involved, we predict the propensity of redox enzymes to degrade dyes, based on bioinformatics research and molecular modeling docking tools (Lohning et al. 2017). We obtained a laccase protein sequence in A. cornea by Protein BLAST. The PDB Format laccase and Mol2 Format small dye molecules were simulated by AutoDock software (Figure 5), and a minimum binding energy of $-28.37 \mathrm{~kJ} / \mathrm{mol}$ was obtained, which was plotted by PyMoL and LigPlus for analysis. It is generally accepted that an energy well occurs when a stable conformation of the ligand and its receptor binding is present (Lin et al. 2020). With a value of binding energy lower than $-5 \mathrm{~kJ} / \mathrm{mol}$, the better the binding effect, and the greater the possibility of action. The laccase-dye complex was tested in vitro to verify the effectiveness of dye bioremediation. The results indicated that the combination of laccase structure prediction via modeling and in vitro analysis is an effective preliminary screening method, which can be further applied to the real-time treatment of toxic wastewater in the textile industry.

\section{Declarations}

Ethical approval Not applicable Not applicable

Consent to participate All the authors agree to participate.

Consent to publish We consent to publish this manuscript in the Environmental Science and Pollution Research. This manuscript has not been published in whole or in part nor is it being considered for publication elsewhere. 
Availability of data and materials All data generated or analyzed during this study are included in this manuscript.

Competing interests The authors declare no competing interests.

Funding This work was financially supported by National Key Research and Development Program of China [grant number 2018YFD1001001].

Authors' contribution Conceived and designed the experiments: LM, LW, WW. Performed the experiments: XRB and SYZ. Analyzed the data: QJW and XRB. Wrote the paper: LM and XRB. Editing and supervision: ZL and XBL. All authors read and approved the final manuscript.

Acknowledgements The authors would like to thank to all who contributed to this study.

\section{References}

Abadulla E, Tzanov T, Costa S, Robra KH, Cavaco-Paulo A, Gubitz GM (2000) Decolorization and detoxification of textile dyes with a laccase from Trametes hirsuta. Applied and Environmental Microbiology 66: 3357.

Asgher M, Shah SAH, Ali M, Legge RL (2006) Decolorization of some reactive dyes by white rot fungi isolated in Pakistan. World Journal of Microbiology Biotechnology 22: 89-93.

Ayed L, Chaieb K, Cheref A, Bakhrouf A (2009) Biodegradation of triphenylmethane dye malachite green by Sphingomonas paucimobilis. World J Microbiol Biotechnol 25: 705-711.

Ayed L, Mahdhi A, Cheref A, Bakhrouf A (2011) Decolorization and degradation of azo dye Methyl Red by an isolated Sphingomonas paucimobilis: Biotoxicity and metabolites 
Bagewadi ZK, Mulla SI, Ninnekar HZ (2017) Optimization of laccase production and its

Couto RS, Herrera JTL (2006) Industrial biotechnological applications of laccases: A review. Biotechnology Advance 24: 500-513.

Daneshvar N, Khataee AR, Rasoulifard MH, Pourhassan M (2007) Biodegradation of dye solution containing Malachite Green: optimization of effective parameters using Taguchi method. J Hazard Mater 143: 214-219.

Erkurt EA, Ali ü, Kumbur H (2007) Decolorization of synthetic dyes by white rot fungi, involving laccase enzyme in the process. Process Biochemistry 42: 1429-1435.

Fernandes C, Lalitha VS, Rao KVK (1991) Enhancing effect of Malachite Green on the development of hepatic pre-neoplastic lesions induced by N-nitrosodiethylamine in rats. Carcinogenesis 12: 839-845. 
Galhaup C, Haltrich D (2001) Enhanced formation of laccase activity by the white rot fungus Trametes pubescens in the presence of copper. Appl Microbiol Biotechnol 56: 225-232.

Galhaup C, Wagner H, Hinterstoisser B, Haltrich D (2002) Increased production of laccase by the wood-degrading basidiomycete Trametes pubescens. Enzyme Microb Technol 30: $529-536$

Ghodake GS, Kalme SD, Jadhav JP, Govindwar SP (2008) Purification and partial characterization of lignin peroxidase from Acinetobacter calcoaceticus NCIM 2890 and its application in decolorization of textile dyes. Applied Biochemistry and Biotechnology 152: 6-14.

Jadhav UU, Dawkar VV, Ghodake GS, Govindwar SP (2008) Biodegradation of Direct Red 5B, a textile dye by newly isolated Comamonas sp. UVS. Journal of Hazardous Materials 158: 507-516.

Jain IA, Gupta VK, Bhatnagar-Suhas A (2003) Utilization of industrial waste products as adsorbents for the removal of dyes. J Hazard Mater B 101: 31-42.

Kumar KV, Ramamurthi V, Sivanesan S (2006) Biosorption of malachite a green, a cationic dye onto Pithophora sp., a fresh water algae. Dyes Pigments 69: 74-79.

Legerská B, Chmelová D, Ondrejovič M (2016) Degradation of synthetic dyes by laccases. Nova Biotechnologica et Chimica 15: 90-106.

Li A, Ge L, Cai J, Pei J, Xie J, Zhao L (2014) Comparison of Two Laccases from Trametes versicolor for Application in the Decolorization of Dyes. J Microbiol Biotechnol 24(4): 545-555.

Lin Z, Tong Y, Li N, Zhu Z, Li J (2020) Network pharmacology-based study of the 
mechanisms of action of anti-diabetic triterpenoids from Cyclocarya paliurus. Royal society of chemistry advances 10: 37168. https://doi.org/10.1039/D0RA06846B

Lohning AE, Levonis SM, Williams-Noonan B, Schweiker SS (2017) A practical guide to molecular docking and homology modelling for medicinal chemists. Current Topics in Medicinal Chemistry 17: 1-18. 
Saratale RG, Saratale GD, Chang JS, Govindwar SP (2011) Bacterial decolorization and degradation of azo dyes: A review. J Taiwan Inst Chem Eng 42, 138-157.

Selvam K, Swaminathan K, Chae KS (2003) Decolourization of azo dyes and a dye industry effluent by a white rot fungus Thelephora sp.. Bioresour Technol 88:115-119.

Sondhi S, Saini K (2019) Response surface based optimization of laccase production from Bacillus sp. MSK-01 using fruit juice waste as an effective substrate. Heliyon 5: e01718.

Songulashvili G, Elisashvili V, Wasser SP, Nevo E, Hadar Y, Basidiomycetes laccase and manganese peroxidase activity in submerged fermentation of food industry wastes, Enzyme Microb Technol 41: 57-61.

Sun X, Zhang R, Zhang Y (2004) Production of lignocellulolytic enzymes by Trametes gallica and detection of polysaccharide hydrolase and laccase activities in polyacrylamide gels. J Basic Microbiol 44: 220-231.

Tauber MM, Guebitz GM, Rehorek A (2005) Degradation of Azo Dyes by Laccase and Ultrasound Treatment. Applied and Environmental Microbiology 71(5): 2600-2607.

Tychanowicz GK, Zilly A, de Souza CGM, Peralta RM (2004) Decolourisation of industrial dyes by solid-state cultures of Pleurotus pulmonarius. Process Biochemistry 39(7): 855-859.

Vršanská M, Voběrková S, Jiménez AMJ, Strmiska V, Adam V (2018) Preparation and Optimisation of Cross-Linked Enzyme Aggregates Using Native Isolate White Rot Fungi Trametes versicolor and Fomes fomentarius for the Decolourisation of Synthetic Dyes. International Journal of Environmental Research and Public Health 15: 23. 
334 Wesenberg D, Kyriakides I, Agathos SN (2003) White-rot fungi and their enzymes for the treatment of industrial dye effluents. Biotechnology Advances 22: 161-187.

336 Zhuo R, Ma L, Fan FF, Gong YM, Wan X, Jiang ML, Zhang XY, Yang Y (2011)

337 Decolorization of different dyes by a newly isolated white-rot fungi strain Ganoderma sp.

338 En3 and cloning and functional analysis of its laccase gene. Journal of Hazardous Materials 192: 855-873.

340 


\title{
Figure Captions
}

342 Figure 1 Effects of time (A), temperature (B), inducer concentration (C) and $\mathrm{pH}(\mathrm{D})$ on the laccase activity of Auricularia cornea.

Figure 2 The influence of the interactions of two combinations of factors on laccase production in Auricularia cornea. (A) Interaction between inducer concentration and $\mathrm{pH}$.

Figure 3 Decolorization analysis of malachite green dye by HPLC. (A) Original sample of (B) Interaction between inducer concentration and time. (C) Interaction between inducer concentration and temperature. (D) Interaction between temperature and time.

\author{
malachite green dye. (B) Malachite green after degradation by A. cornea AC5 for $12 \mathrm{~h}$.
}

Figure 4 Cytotoxic damage induced in root meristematic cells of Allium sativum on treatment with malachite green. The black arrow in the picture refers to the chromosome variant cells. (A) micronucleus, (B) chromosome bridge.

Figure 5 Structural model of molecular docking complex. (A) 3D model of molecular docking complex of laccase from A. cornea AC5 and Malachite green. (B) 2D ligand-receptor interaction diagram. Ligand interaction diagram indicating in detail how these residues interact with the ligand. Note the interactions between amino groups and acidic residues, specifically at Asn82, Ser135, Glu175, Ala537, Asp539, Phe536, and Asp178. 
Table 1 Factors and coded levels of the central composite design

\begin{tabular}{lllll}
\hline \multirow{2}{*}{ Factors } & Code & \multicolumn{3}{l}{ Level } \\
\cline { 3 - 5 } & & -1 & 0 & 1 \\
\hline Time $(\mathrm{d})$ & $\mathrm{A}$ & 3 & 5 & 7 \\
Temperature $\left({ }^{\circ} \mathrm{C}\right)$ & $\mathrm{B}$ & 22 & 26 & 30 \\
Inducer concentration $(\%)$ & $\mathrm{C}$ & 5 & 7.5 & 10 \\
$\mathrm{pH}$ & $\mathrm{D}$ & 5 & 6 & 7 \\
\hline
\end{tabular}
Auricularia cornea

\begin{tabular}{|c|c|c|c|c|c|}
\hline \multirow{2}{*}{$\begin{array}{l}\text { Run } \\
\text { No. }\end{array}$} & \multicolumn{4}{|c|}{ Factors } & \multirow{2}{*}{$\begin{array}{l}\text { Laccase activity } \\
(\mathrm{U} / \mathrm{mL})\end{array}$} \\
\hline & $\begin{array}{l}\text { A: Time } \\
\text { (h) }\end{array}$ & $\begin{array}{l}\text { B: Temperature } \\
\left({ }^{\circ} \mathrm{C}\right)\end{array}$ & $\begin{array}{l}\text { C: Inducer concentration } \\
(\%)\end{array}$ & $\mathrm{D}: \mathrm{pH}$ & \\
\hline 1 & 0 & -1 & 0 & 1 & 61.91 \\
\hline 2 & -1 & 0 & 0 & 1 & 282.59 \\
\hline 3 & -1 & 0 & 1 & 0 & 205.56 \\
\hline 4 & 1 & -1 & 0 & 0 & 302.23 \\
\hline 5 & 0 & 1 & 0 & 1 & 218.62 \\
\hline 6 & 0 & -1 & 1 & 0 & 310.66 \\
\hline 7 & 0 & 0 & -1 & -1 & 466.35 \\
\hline 8 & -1 & 0 & -1 & 0 & 220.78 \\
\hline 9 & -1 & -1 & 0 & 0 & 118.98 \\
\hline 10 & 0 & -1 & 0 & -1 & 404.03 \\
\hline 11 & 0 & 0 & 1 & -1 & 654.33 \\
\hline 12 & -1 & 1 & 0 & 0 & 0.62 \\
\hline 13 & 0 & 0 & 0 & 0 & 593.35 \\
\hline 14 & -1 & 0 & 0 & -1 & 224.28 \\
\hline 15 & 1 & 1 & 0 & 0 & 590.67 \\
\hline 16 & 0 & 1 & 0 & -1 & 418.63 \\
\hline 17 & 0 & 1 & -1 & 0 & 537.51 \\
\hline 18 & 0 & 0 & 0 & 0 & 580.91 \\
\hline 19 & 0 & -1 & -1 & 0 & 485.06 \\
\hline 20 & 0 & 0 & -1 & 1 & 572.27 \\
\hline 21 & 1 & 0 & 1 & 0 & 535.76 \\
\hline 22 & 1 & 0 & 0 & 1 & 226.03 \\
\hline 23 & 1 & 0 & -1 & 0 & 637.88 \\
\hline 24 & 0 & 0 & 0 & 0 & 555.19 \\
\hline 25 & 1 & 0 & 0 & -1 & 639.93 \\
\hline 26 & 0 & 0 & 1 & 1 & 57.90 \\
\hline 27 & 0 & 1 & 1 & 0 & 316.11 \\
\hline
\end{tabular}




\begin{tabular}{ccccccc}
\hline Sources & Sum of squares & Df & $\begin{array}{c}\text { Sum of } \\
\text { squares }\end{array}$ & F value & P value & Significant \\
\hline Model & 995899.3315 & 14 & 71135.66653 & 16.37894561 & $<0.0001$ & significant \\
A-A & 13286.82951 & 1 & 13286.82951 & 3.059284722 & 0.1058 & \\
B-B & 294436.3645 & 1 & 294436.3645 & 67.79380069 & $<0.0001$ & \\
C-C & 58734.40499 & 1 & 58734.40499 & 13.52356239 & 0.0032 & \\
D-D & 160603.1719 & 1 & 160603.1719 & 36.97878638 & $<0.0001$ & \\
AB & 41373.32278 & 1 & 41373.32278 & 9.526183368 & 0.0094 & \\
AC & 552.1285939 & 1 & 552.1285939 & 0.127127286 & 0.7276 & \\
AD & 5049.215677 & 1 & 5049.215677 & 1.162578956 & 0.3021 & \\
BC & 1887.649052 & 1 & 1887.649052 & 0.43463009 & 0.5222 & \\
BD & 55745.72847 & 1 & 55745.72847 & 12.83542137 & 0.0038 & \\
CD & 123324.4659 & 1 & 123324.4659 & 28.39538614 & 0.0002 & \\
A $^{\wedge} 2$ & 156509.844 & 1 & 156509.844 & 36.03630002 & $<0.0001$ & \\
$B^{\wedge} 2$ & 110241.9735 & 1 & 110241.9735 & 25.3831499 & 0.0003 & \\
$C^{\wedge} 2$ & 1525.808184 & 1 & 1525.808184 & 0.351316442 & 0.5644 & \\
$D^{\wedge} 2$ & 68799.19201 & 1 & 68799.19201 & 15.84097371 & 0.0018 & \\
Residual & 52117.39626 & 12 & 4343.116355 & & & \\
Lack of fit & 51359.82189 & 10 & 5135.982189 & 13.55901791 & 0.0706 & not significant \\
Pure error & 757.5743644 & 2 & 378.7871822 & & & \\
Cor total & 1048016.728 & 26 & & & & \\
\hline & & & & & & \\
\hline
\end{tabular}


Figures
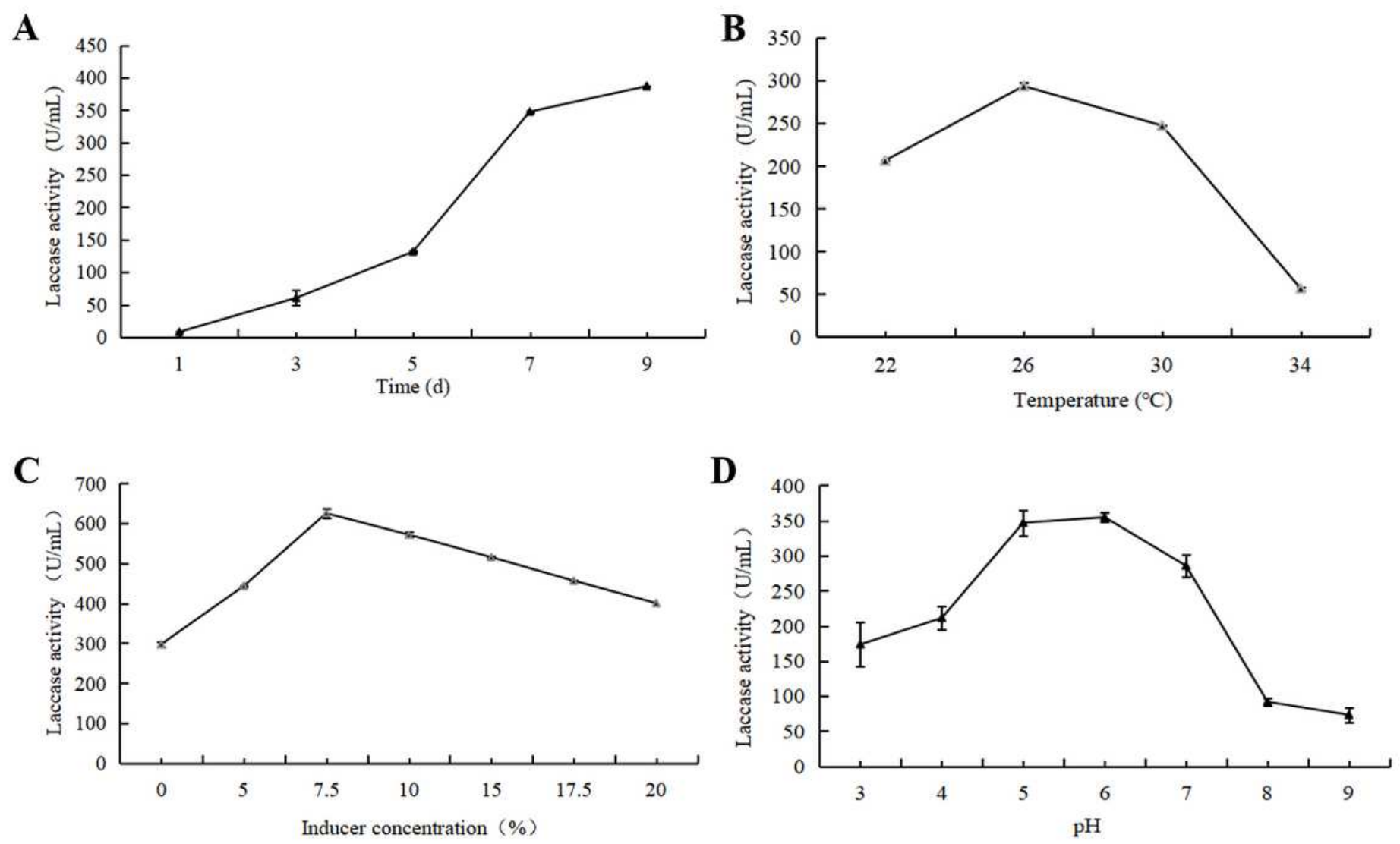

Figure 1

Effects of time (A), temperature (B), inducer concentration (C) and $\mathrm{pH}(\mathrm{D})$ on the laccase activity of Auricularia cornea. 

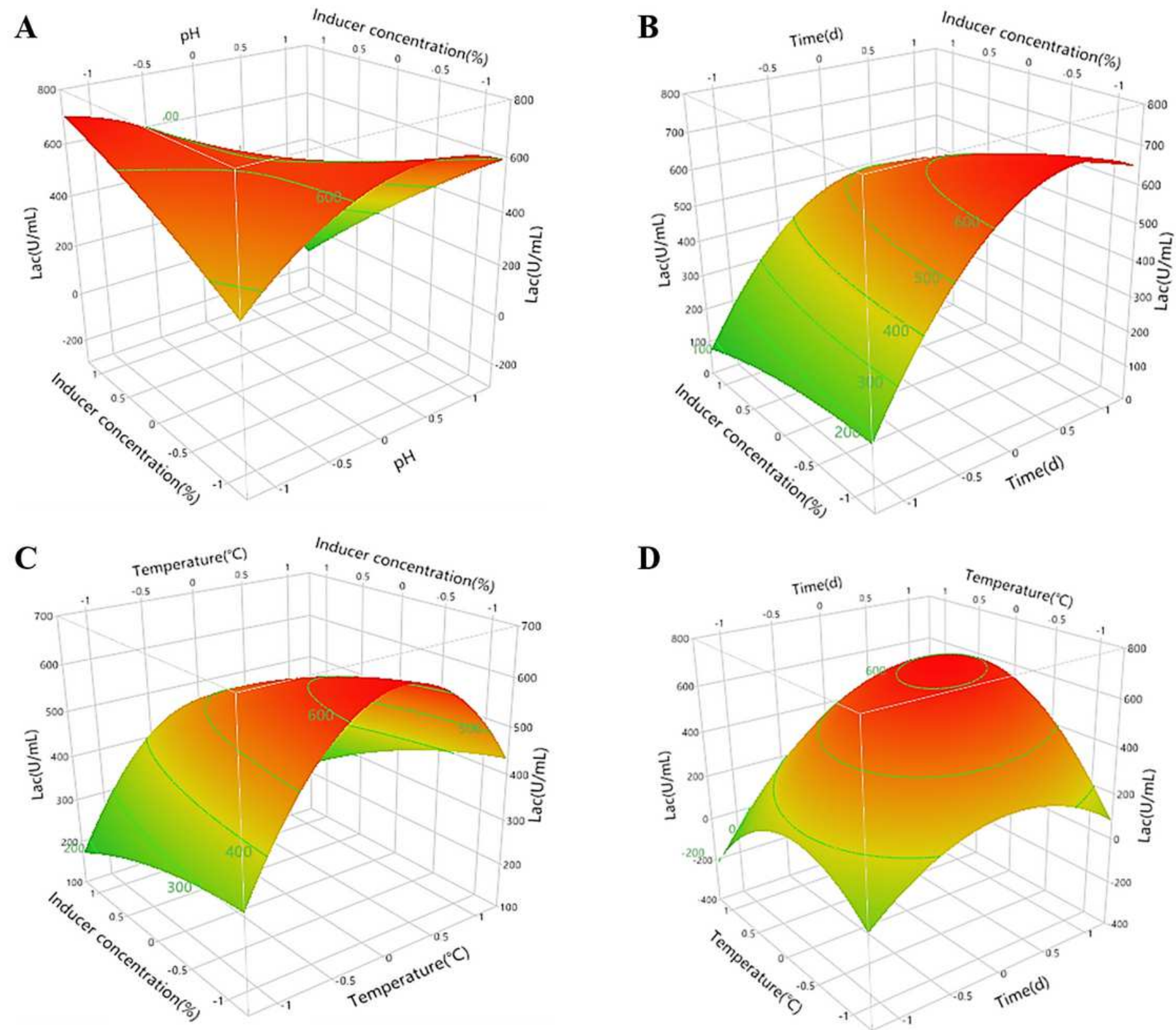

\section{Figure 2}

The influence of the interactions of two combinations of factors on laccase production in Auricularia cornea. (A) Interaction between inducer concentration and $\mathrm{pH}$. (B) Interaction between inducer concentration and time. (C) Interaction between inducer concentration and temperature. (D) Interaction between temperature and time. 

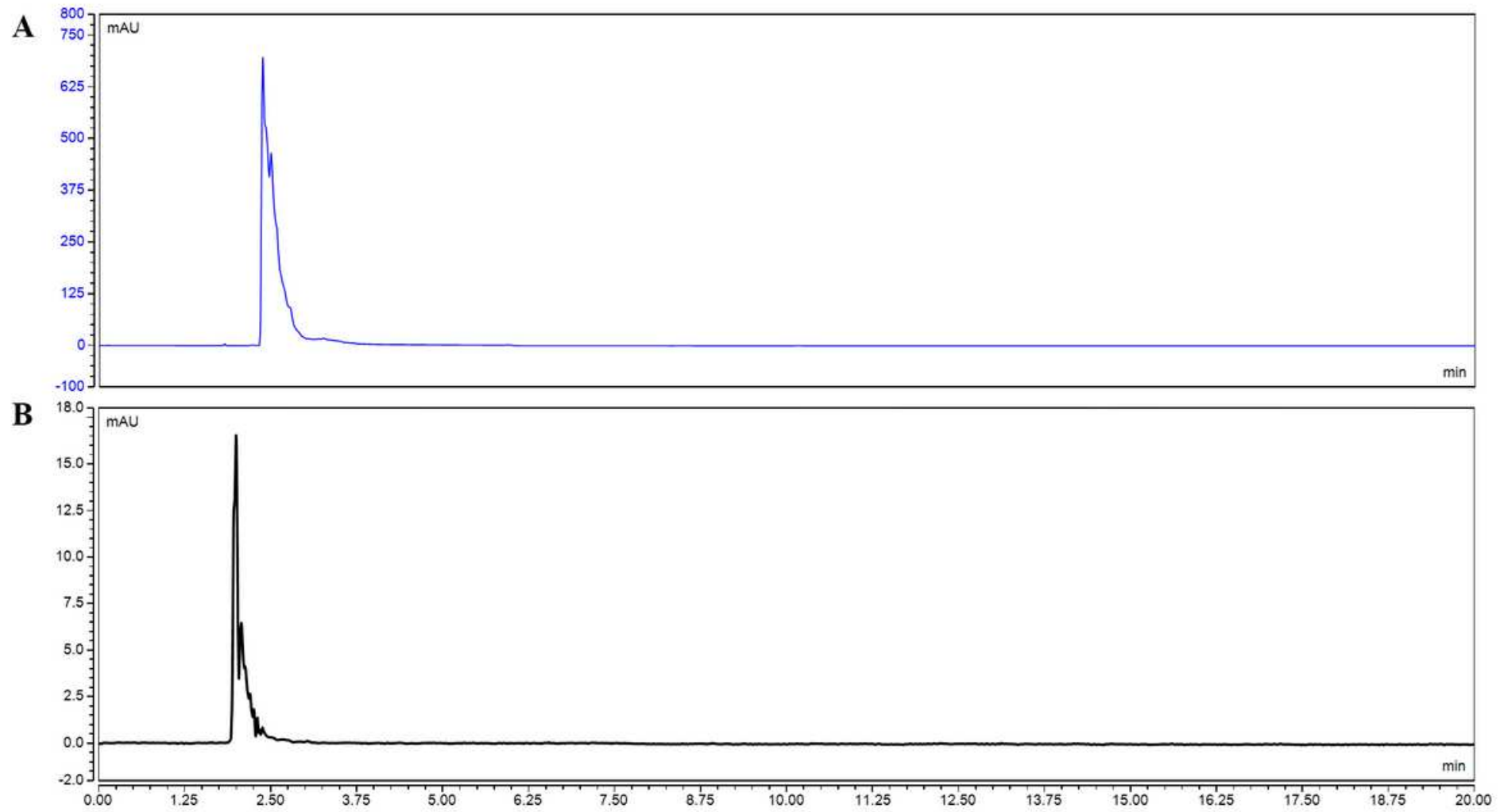

\section{Figure 3}

Decolorization analysis of malachite green dye by HPLC. (A) Original sample of malachite green dye. (B) Malachite green after degradation by A. cornea AC5 for $12 \mathrm{~h}$.

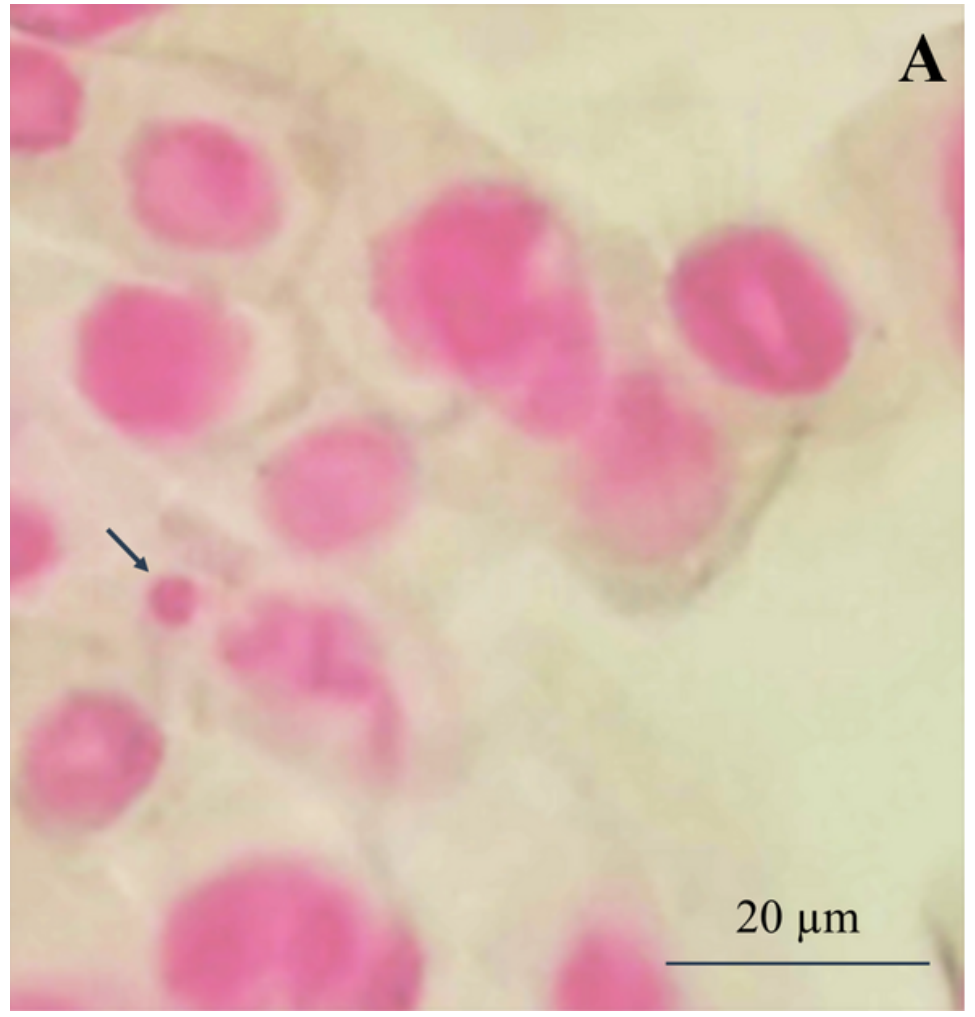

B

Figure 4 
Cytotoxic damage induced in root meristematic cells of Allium sativum on treatment with malachite green. The black arrow in the picture refers to the chromosome variant cells. (A) micronucleus, (B) chromosome bridge.
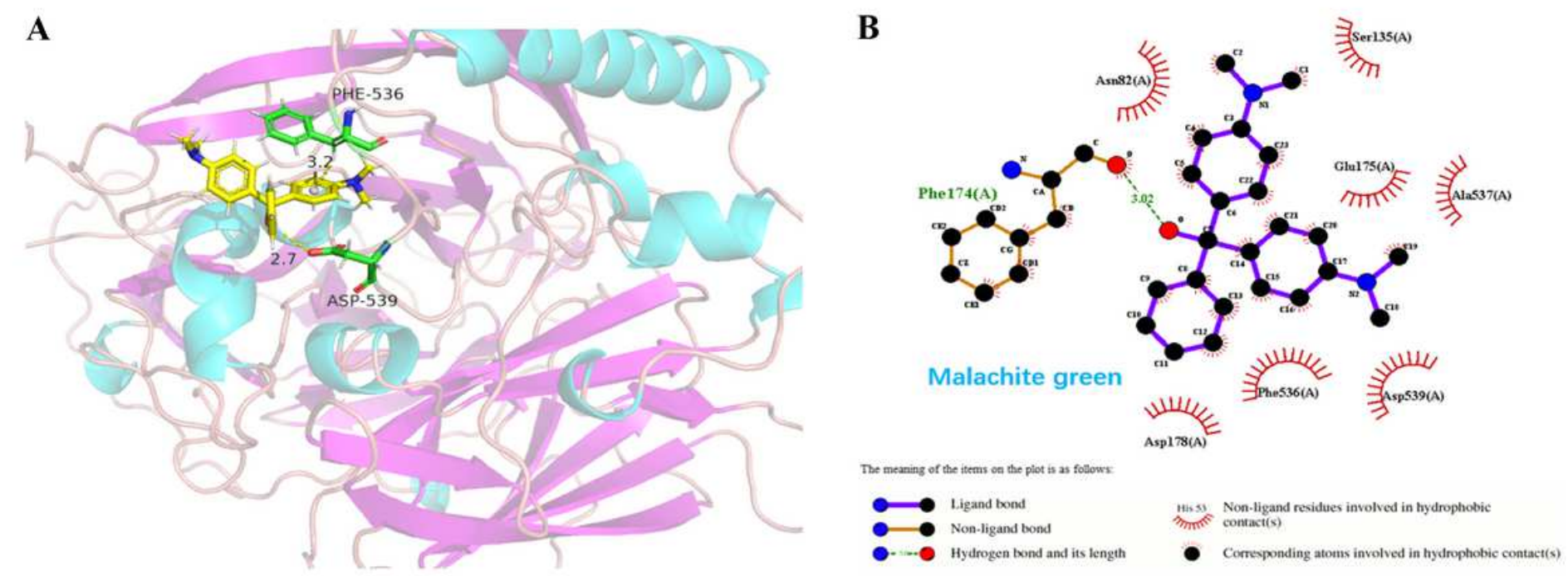

\section{Figure 5}

Structural model of molecular docking complex. (A) 3D model of molecular docking complex of laccase from A. cornea AC5 and Malachite green. (B) 2D ligand-receptor interaction diagram. Ligand interaction diagram indicating in detail how these residues interact with the ligand. Note the interactions between amino groups and acidic residues, specifically at Asn82, Ser135, Glu175, Ala537, Asp539, Phe536, and Asp178. 